\title{
ANALISIS REMBESAN TERHADAP KEAMANAN BENDUNGAN KEDUNG OMBO DI KABUPATEN GROBOGAN, JAWA TENGAH
}

\section{SEEPAGE ANALYSIS OF KEDUNG OMBO DAM SAFETY IN GROBOGAN DISTRICT, CENTRAL JAVA}

\section{Rais Buldan ${ }^{1)^{*}}$ Suharyanto ${ }^{2)}$ Najib $^{3)}$ Kresno Wikan Sadono ${ }^{4]}$}

\author{
1)Balai Besar Wilayah Sungai Sumatera VIII Kementerian PUPR \\ Jl. Soekarno Hatta No.869, Alang-Alang Lebar, Palembang, Indonesia \\ 2,4) Departemen Teknik Sipil Universitas Diponegoro \\ Jl. Prof. Sudarto No.13, Tembalang, Semarang, Indonesia \\ 3) Departemen Teknik Geologi Universitas Diponegoro \\ Jl. Prof. Sudarto No.13, Tembalang, Semarang, Indonesia \\ *Correspondence email: raisbuldan@pu.go.id
}

Diterima: 28 April 2021; Direvisi: 20 Juni 2021; Disetujui: 19 September 2021

\begin{abstract}
A dam, besides having a great benefits to meet human needs, it also can be a big disaster in addition to the dam collapsing. One of the main causes offailure of an embankment dam is the occurrence of excessive seepage which triggers piping events that can disturb the stability and safety of the dam. In general, the body of the Kedung Ombo Dam is in good condition, but there are several problems, such as the drain holes that are overgrown with dense grass which indicates that seepage has occurred. Therefore, it is necessary to evaluate the seepage to determine the safety level of the Kedung Ombo Dam. This study aims to analyze the condition of pore water pressure and seepage that occurs in the body of the Kedung Ombo Dam and to determine the level of safety of the dam body. The analyze was carried out using seepage monitoring instruments installed on the dam, namely the Piezometer and V-Notch at the Kedung Ombo Dam in 2021. Based on the results of the analysis, it was found that the pore water pressure and seepage discharge that occurred in the Kedung Ombo Dam were generally still within the permissible limits. According to the analysis results of the seepage index, the highest QI value is 0.09 at the maximum flood water level of $+95 \mathrm{~m}$, where the safety criteria for the seepage index is $Q I<1$. Therefore it indicates that the seepage condition index at the Kedung Ombo Dam are still in a safe condition.
\end{abstract}

Keywords: pore water pressure, seepage, piezometer, V-Notch, seepage index

\section{ABSTRAK}

Bendungan selain memiliki manfaat yang besar untuk memenuhi kebutuhan manusia, bendungan juga dapat berpotensi menjadi bencana yang besar pula apabila bendungan tersebut runtuh. Salah satu penyebab utama kegagalan suatu bendungan tipe urukan adalah terjadinya rembesan berlebih yang memicu terjadinya piping yang dapat mengganggu kestabilan dan keamanan bendungan. Secara umum kondisi tubuh Bendungan Kedung Ombo dalam kondisi baik, namun terdapat beberapa permasalahan antara lain seperti lubang drainase ditumbuhi rumput lebat yang mengindikasikan adanya rembesan yang terjadi. Oleh karena itu diperlukan evaluasi terhadap rembesan untuk mengetahui tingkat keamanan Bendungan Kedung Ombo. Penelitian ini bertujuan untuk menganalisis kondisi tekanan air pori dan rembesan yang terjadi pada tubuh Bendungan Kedung Ombo serta untuk mengetahui tingkat keamanan tubuh bendungan. Analisis dilakukan dengan menggunakan instrumen pemantau rembesan yang terpasang pada bendungan yaitu Piezometer dan $V$-Notch pada Bendungan Kedung Ombo tahun 2021. Berdasarkan hasil analisis diperoleh bahwa tekanan air pori dan debit rembesan yang terjadi pada tubuh Bendungan Kedung Ombo secara umum masih dalam batas yang diizinkan. Berdasarkan hasil analisis seepage index, Nilai QI tertinggi sebesar 0,09 pada elevasi muka air banjir maksimum $+95 \mathrm{~m}$, di mana kriteria keamanan seepage index QI<1. Berdasarkan seepage index kondisi rembesan pada Bendungan Kedung Ombo masih dalam kondisi aman.

Kata Kunci: tekanan air pori, rembesan, piezometer, V-Notch, indeks rembesan 


\section{PENDAHULUAN}

Bendungan merupakan suatu bangunan air yang dibangun dan berfungsi sebagai penampung air untuk memenuhi kebutuhan manusia. Bendungan adalah bangunan yang berupa urukan tanah, urukan batu, beton, dan/atau pasangan batu yang dibangun selain untuk menahan dan menampung air, dapat pula dibangun untuk menahan dan menampung limbah tambang, atau menampung lumpur sehingga terbentuk waduk (Indonesia, 2010).

Selain memiliki manfaat yang besar untuk memenuhi kebutuhan manusia, bendungan juga dapat berpotensi menjadi bencana yang besar pula apabila bendungan tersebut runtuh. Apabila suatu bendungan runtuh maka akan menimbulkan banjir bandang yang dapat menyebabkan kerugian yang sangat besar baik jatuhnya korban jiwa, kehilangan harta benda, kerusakan infrastruktur dan kerusakan lingkungan. Sebagai contoh pada tanggal 27 Maret 2009, Situ Gintung yang terletak di Kota Tangerang Selatan, Provinsi Banten, mengalami keruntuhan dan membanjiri daerah di hilirnya. Sekitar 100 orang dilaporkan tewas dan sejumlah orang hilang serta kerugian harta benda mencapai 10 Miliyar Rupiah. Bendungan memiliki potensi bahaya tinggi bagi kehidupan dan harta benda jika terjadi kerusakan atau jebolnya tanggul (Sujono, 2012).

Kegagalan pada bendungan dapat terjadi dikarenakan oleh banyak faktor. Beberapa penyebab utama kegagalan bendungan yaitu : limpasan (overtopping), rembesan (seepage), longsoran (slope stability) dan penyebab lain (gempa, likuifaksi, sabotase, dan lain lain). Kegagalan bendungan yang terjadi dikarenakan oleh rembesan merupakan yang paling tinggi dibandingankan faktor yang lain, yaitu sebesar $43 \%$ (Azdan \& Samekto, 2008)

Penelitian yang dilakukan oleh Balai Keamanan Bendungan terhadap 122 bendungan urukan, menyimpulkan bahwa terdapat $20 \%$ kasus kerawanan bendungan, sebesar 59\%-nya merupakan bendungan dengan usia operasi di atas 25 tahun, sedangkan $41 \%$ sisanya merupakan bendungan dengan usia lebih muda dari 25 tahun (Balai Keamanan Bendungan, 2000).

Berdasarkan data di atas dapat dilihat bahwa salah satu penyebab utama kegagalan suatu bendungan tipe urukan adalah terjadinya rembesan yang memicu terjadinya piping sehingga menyebabkan kestabilan dan keamanan bendungan terganggu. Untuk mencegah terjadinya rembesan yang membahayakan, perlu dilakukan pemantauan dan evaluasi terhadap kondisi rembesan pada bendungan yang biasanya dilakukan menggunakan instrumen piezometer yang dipasang pada tubuh bendungan dan instrumen $V$-Notch yang dipasang pada kaki hilir bendungan (toe drain) (Foster et al., 2000). Rembesan yang terjadi dipengaruhi oleh koefisien permeabilitas material $(\mathrm{k})$, gradien hidrolis (i) dan ketinggian muka air waduk $(\Delta \mathrm{h})$ (Wulandari \& Tjandra, 2019).

Tekanan hidrostatis mempengaruhi kecepatan rembesan dimana semakin tinggi tekanan hidrostatis pada bendungan maka akan semakin besar jumlah rembesan dan semakin pendek waktu yang dibutuhkan untuk merembes (Nurnawaty et al., 2018). Seiring dengan naiknya ketinggian muka air waduk, terjadi kenaikan nilai tekanan air pori dan rembesan (Huda et al., 2019). Variasi laju muka air mempengaruhi tekanan air pori. Intensitas curah hujan memperngaruhi tekanan air pori di bagian hulu bendungan, dan semakin tinggi curah hujan, perubahan tekanan air pori semakin tinggi pula (Zhang et al., 2020). Kemiringan hulu yang berbeda untuk simulasi bendungan urukan dimana menunjukkan semakin tinggi kemiringan hulu, jumlah rembesan dari bendungan meningkat dan keamanan bendungan menurun (El-Hazek et al., 2020).

Instrumentasi pada bendungan bertujuan untuk mengamati seluruh perilaku tubuh bendungan secara seksama, sehingga dapat diketahui kondisi-kondisi yang sebenarnya. Berdasarkan data-data yang didapatkan dari instrumen tersebut diharapkan dapat diketahui apakah tubuh bendungan masih dalam kondisi yang normal ataukah sudah terjadi indikasi ketidakstabilan yang dapat menyebabkan timbulnya bahaya terhadap keamanan bendungan, sehingga dapat diantisipasi sebelumnya.

Bendungan Kedung Ombo dibangun setelah dilakukan survei, investigasi dan studi kelayakan yang dilaksanakan oleh P3SA bersama NEDECO (Netherland) tahun 1969. Waduk Kedung Ombo diresmikan pada tanggal 18 Mei 1991 dan beroperasi hingga saat ini. Seiring dengan kurun pengoperasian Waduk Kedung Ombo sejak diresmikan hingga saat ini (lebih dari 30 tahun), diperlukan kegiatan inspeksi waduk/bendungan secara rutin dan teratur. Kegiatan tersebut diperlukan agar kelestarian fungsi bangunan tetap terjaga sesuai dengan yang direncanakan serta dalam rangka evaluasi keamanan bendungan.

Berdasarkan hasil inspeksi visual pada tanggal 15 Maret 2021, secara umum kondisi tubuh Bendungan Kedung Ombo dalam kondisi baik, namun terdapat beberapa permasalahan antara lain seperti lubang drain yang ditumbuhi rumput lebat yang mengindikasikan adanya rembesan yang 
terjadi, beberapa tempat tampak adanya penurunan kecil, pada puncak bendungan dijumpai adanya retakan-retakan memanjang dan bekas retakan memanjang yang sudah diperbaiki. Pada daerah hilir kaki bendungan ditemukan tonjolan pada permukaan aspal dengan diameter $5 \mathrm{~m}$ dimana ada kemungkinan terjadi deformasi internal.

Studi mengenai rembesan pada Bendungan Panohan, di mana kebocoran rembesan terjadi hingga memotong lereng hilir bendungan yang dapat mengganggu stabilitas tubuh bendungan. Evaluasi tekanan air pori dan rembesan di tubuh Bendungan Panohan dilakukan dengan menggunakan metode analisis instrumentasi piezometer dan $V$-Notch. Berdasarkan hasil analisis diperoleh bahwa kondisi rembesan yang terjadi pada Bendungan Panohan tidak aman terhadap kondisi muka air banjir (Huda et al., 2019)

Penelitian ini bertujuan untuk menganalisis kondisi tekanan air pori dan rembesan yang terjadi pada tubuh Bendungan Kedung Ombo serta untuk mengetahui tingkat keamanan tubuh bendungan. Analisis dilakukan berdasarkan data hasil pengamatan instrumen piezometer dan $V$-Notch yang terpasang pada tubuh Bendungan Kedung Ombo. Dari hasil tersebut, diharapkan dapat dihasilkan evaluasi rembesan yang terjadi pada tubuh bendungan.

\section{METODOLOGI}

Studi analisis rembesan ini dilakukan pada Bendungan Kedung Ombo dilaksanakan pada tahun 2021. Bendungan Kedung Ombo berlokasi pada pertemuan Sungai Uter dan Sungai Serang yang terletak di Dukuh Kedung Ombo Desa Ngrambat, Kecamatan Geyer, Kabupaten Grobogan, Provinsi Jawa Tengah. Secara geografi Bendungan Kedung Ombo berada pada koordinat 70 15' 33" LS dan $110^{\circ}$ 50' 18" BT.. Untuk lebih jelasnya dapat dilihat pada Gambar 1.

Data yang digunakan dalam penelitian ini adalah data sekunder yang diperoleh dari Balai Besar Wilayah Sungai (BBWS) Pemali Juana. Data sekunder tersebut berupa data pelaksanaan proyek pembangunan Bendungan Kedung Ombo dan hasil pencatatan instrumentasi yang terpasang pada tubuh bendungan. Selain itu juga digunakan datadata dari standar, literatur dan penelitian sebelumnya sebagai pendekatan untuk menganalisis permasalahan yang terkait pada penelitian ini. Data-data yang digunakan dalam penelitian ini adalah sebagai berikut.
Bendungan utama (main dam) adalah bendungan urukan tanah dan batu dengan inti (core) tegak, lereng hulu dari inti tersebut dilindungi dengan filter transisi dan zona timbunan batu dengan perlindungan rip-rap. Lereng hilir dari inti juga dilengkapi dengan filter halus kemudian filter transisi dan timbunan random. Gambar potongan melintang Bendungan Kedung Ombo dapat dilihat pada Gambar 2.

Instrumen Piezometer berfungsi untuk memantau perubahan tekanan air pori pada tubuh bendungan dan pondasi. Bendungan Kedung Ombo terdapat 80 buah yang terdiri atas piezometer tipe elektrik sebanyak 32 buah dan tipe hidraulik sebanyak 48 buah. Piezometer tersebut tersebar di dalam pondasi, filter dan inti bendungan. Kondisi piezometer hidraulik secara umum masih baik dan normal. Kondisi Piezometer elektrik secara umum juga dalam kondisi baik, kecuali EP4, EP7 dan EP8 pembacaan tidak dapat dilakukan secara normal.

Rembesan di Bendungan Kedung Ombo diamati melalui seepage observation berupa V-Notch. $V$ Notch berfungsi untuk mengukur rembesan yang berasal dari tampungan waduk. Terdapat 6 buah $V$ Notch untuk memantau rembesan. Saat ini kondisi $V$-Notch yang masih dalam kondisi yang baik sebanyak 3 (tiga) buah yaitu W2, W3, dan W4, sedangkan 3 (tiga) buah yang lainnya dalam keadaan rusak. Lokasi $V$-Notch dapat dilihat pada Gambar 3 .

Data geometri bendungan diperoleh dari gambar as built drawing proyek pembangunan Bendungan Kedung Ombo. Data tersebut diperlukan untuk lokasi penempatan instrumen piezometer dan V-Notch. Gambar lokasi piezometer hidraulik dan piezometer elektrik dapat dilihat pada Gambar 2 dan Gambar lokasi V-Notch dapat dilihat pada Gambar 3.

Data hasil pembacaan Instrumentasi pemantau rembesan Bendungan Kedung Ombo diperoleh dari pengamatan langsung pada instrumentasi dari beberapa kurun waktu tertentu. Beberapa data instrumentasi yang diperlukan dalam penelitian ini antara lain :
a. Data pembacaan instrumentasi piezometer dan $V$-Notch pada bendungan
b. Data pencatatan muka air waduk
c. Data pencatatan curah hujan Rain Gauge 


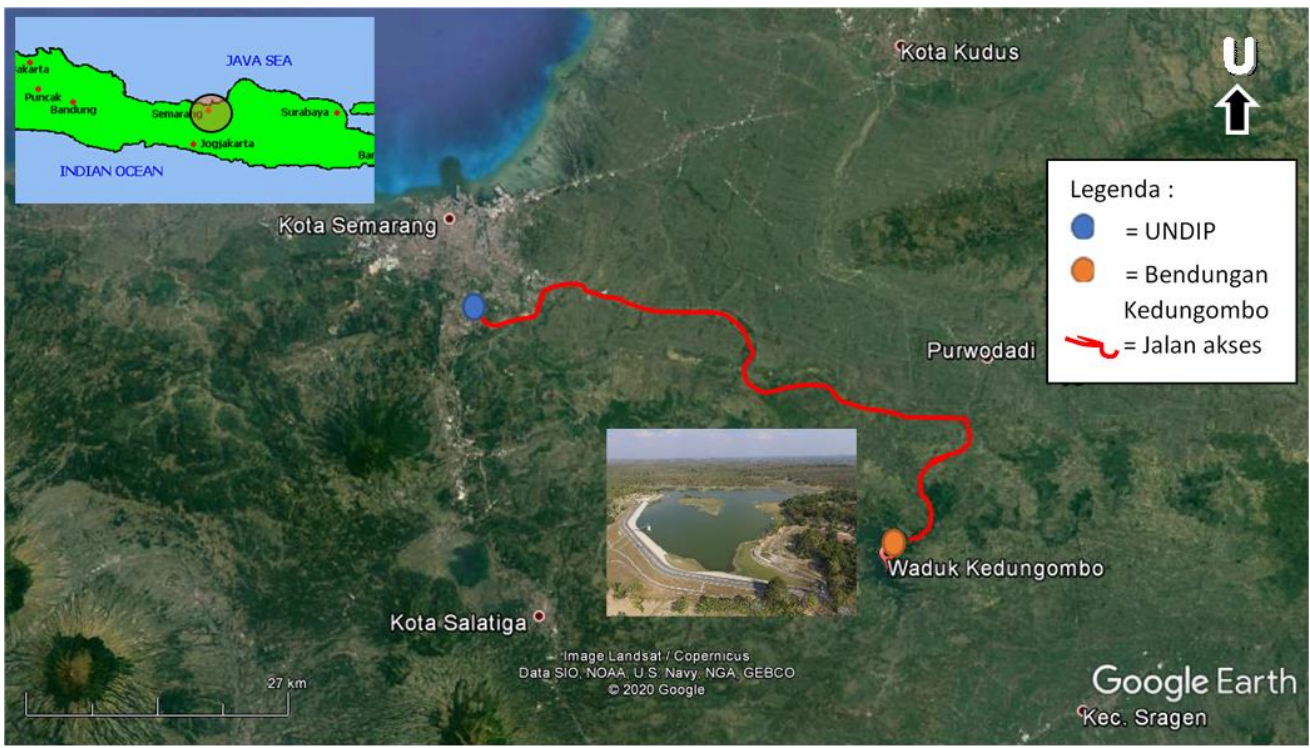

Gambar 1 Peta Lokasi Bendungan Kedung Ombo

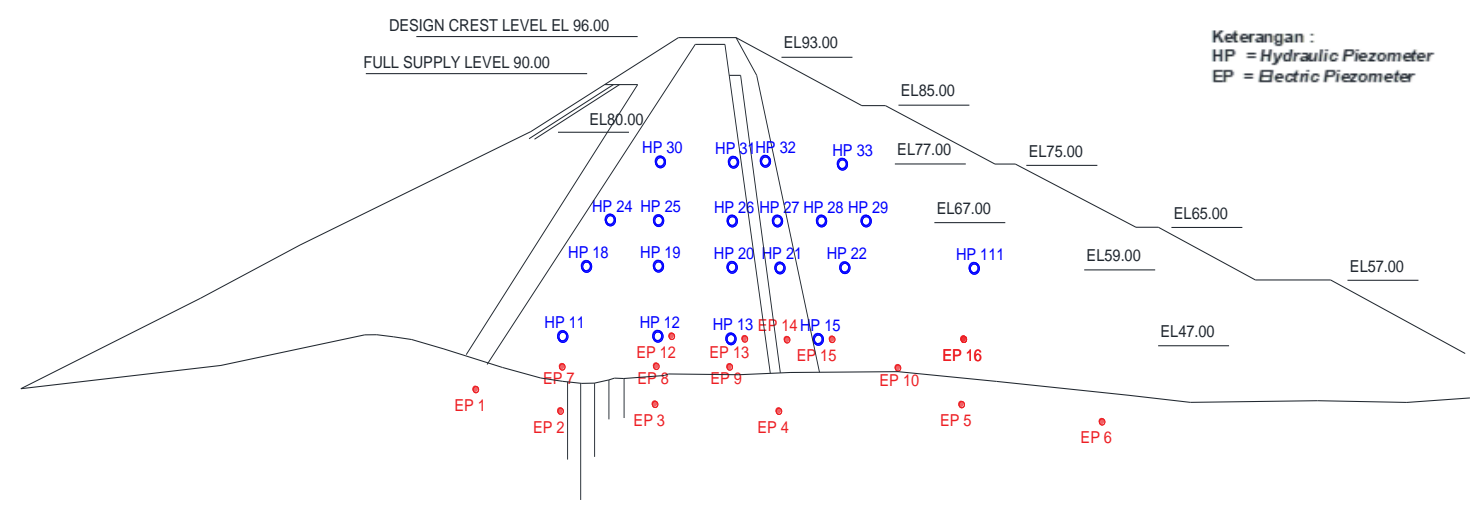

Gambar 2 Potongan melintang dan lokasi piezometer hidraulik dan elektrik Bendungan Kedung Ombo

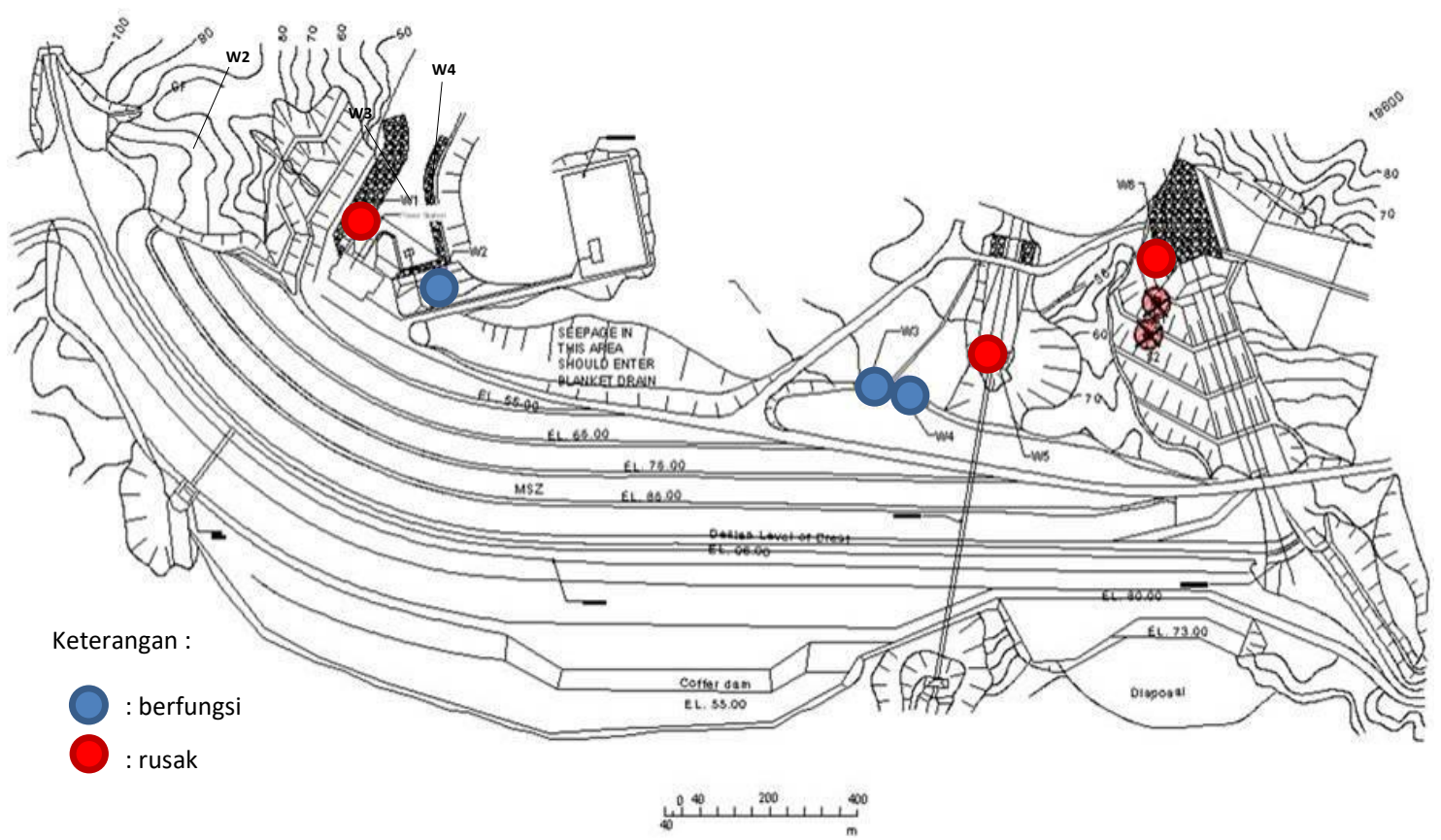

Gambar 3 Lokasi $V$-Notch Bendungan Kedung Ombo 
Dari data tersebut selanjutnya dipilih data yang menggambarkan kondisi perilaku bendungan pada muka air normal maksimum dan muka air banjir. Pengamatan tekanan air pori erat kaitannya dengan elevasi muka air waduk. Setiap kenaikan air muka waduk maka akan terjadi kenaikan tekanan air pori di dalam tubuh bendungan. Untuk zona inti (core) perubahan tekanan air pori terjadi lebih lamban dibandingkan dengan zona lainnya karena permeabilitasnnya yang lebih kecil. Oleh karena itu, dalam pemantauan tekanan air pori selalu dihubungkan dengan elevasi muka air waduk.

Cara untuk mengetahui elevasi tekanan air pori dari bacaan piezometer adalah dengan menambahkan elevasi titik piezometer yang dipasang pada tubuh bendungan dengan hasil bacaan seperti pada persamaan (1). Pembacaan piezometer mempunyai cara yang berbeda-beda tergantung tipe piezometer tersebut. Dari pembacaan piezometer yang telah dilakukan, akan didapatkan data elevasi air pori pada tiap instrumen piezometer yang kemudian dapat dikorelasikan hasil pembacaan antar piezometer tersebut guna menggambarkan bentuk garis freatik bendungan (CDSO, 2016).

$$
\text { Tinggi tekanan = reading + elevasi }
$$

Pengukuran rembesan dapat dilakukan dengan melihat elevasi air pada skala yang ditentukan pada dinding saluran di hulu dari V-Notch. Rembesan dapat diukur dengan menggunakan persamaan (2). Dari perhitungan menggunakan rumus tersebut akan menghasilkan nilai debit rembesan yang terjadi pada bendungan (Triadmojo, B, 2016).

$$
Q=1,417 \times\left(\frac{h}{100}\right)^{5 / 2}
$$

dimana :

$$
\begin{aligned}
& Q \quad \text { : Debit rembesan }\left(\mathrm{m}^{3} / \mathrm{s}\right) \\
& h \quad \text { : Tinggi muka air pada } V \text {-Notch }(\mathrm{cm})
\end{aligned}
$$

Pemilihan data piezometer dan $V$-Notch yang digunakan dalam studi ini adalah dengan cara mengkombinasikan antara data pencatatan muka air waduk, piezometer dan V-Notch dalam satu grafik pembacaan. Dari grafik yang telah dibuat akan terlihat beberapa kondisi tinggi muka air waduk. Pada tanggal pencatatan muka air yang dipilih harus dalam keadaan tidak terjadi hujan dan tidak dipengaruhi oleh pengaruh musim hujan. Salah satu cara untuk meningkatkan validitas hasil pembacaan instrumen rembesan adalah dengan cara memisahkan data pembacaan rembesan yang terpengaruh tail water dan hujan (FEMA, 2015).

Analisis ekstrapolasi dilakukan untuk mendapatkan tekanan air pori dan debit rembesan pada saat elevasi muka air banjir. Sebelum dilakukan ekstrapolasi, dilakukan analisis regresi terhadap data yang telah diperoleh tersebut dengan cara menghitung koefisien korelasi. Koefisien korelasi digunakan untuk mengetahui hubungan antar dua variabel, yaitu elevasi muka air waduk dan debit rembesan. Semakin kuat korelasi antara dua variable maka nilai koefisien korelasi semakin mendekati satu (metode penelitian kuantitatif, kualitatif,dan $R \& D, 2016)$. Interpretasi nilai koefisien korelasi dapat dilihat pada Tabel 1.

Tabel 1 Interpretasi Koefisien Korelasi

\begin{tabular}{c|c}
\hline Interval Koefisien & Koefisien Korelasi \\
\hline $0,00-0,199$ & Sangat Rendah \\
\hline $0,20-0,399$ & Rendah \\
\hline $0,40-0,599$ & Sedang \\
\hline $0,60-0,799$ & Tinggi \\
\hline $0,80-1,000$ & Sangat Tinggi \\
\hline Sumber: & Sugiyono, 2016
\end{tabular}

Hasil dari analisis ini adalah mengetahui nilai tekanan air pori dan garis freatik yang merupakan batas antara zona jenuh dan tak jenuh pada bendungan dengan cara melakukan korelasi elevasi tekanan air pori pada tiap titik piezometer pada penampang bendungan dari beberapa elevasi muka air waduk. Selain itu juga dapat diketahui debit rembesan yang terjadi pada bendungan dari pembacaan $V$-Notch yang ada pada bendungan dari beberapa variasi elevasi muka air waduk. Data ketinggian muka air dengan curah hujan nol tersebut berisi ketinggian muka air dan debit rembesan, sehingga didapat tinggi muka air pada kondisi operasional yang dapat dibagi dalam kondisi normal dan banjir.

Pada umumnya batas jumlah rembesan maksimum dikaitkan dengan tinggi bendungan, lebar drainase, dan permeabilitas dari inti (core) serta berfungsi tidaknya filter di hulu dan hilir Bendungan. Toleransi terhadap rembesan yang melalui bendungan dapat ditinjau dari jumlah rembesan dan toleransi keamanannya berdasarkan nilai seepage index dan gradien hidrolik. Menurut (Quies 2002 dalam Look 2007) jumlah rembesan yang diizinkan ditampilkan pada Tabel 2.

Tabel 2 Kriteria rembesan pada tubuh bendungan

\begin{tabular}{c|c|c}
\hline \multirow{2}{*}{ Dam height $(m)$} & \multicolumn{2}{|c}{$\begin{array}{c}\text { Seepage : Litres/day/meter } \\
\text { (Litres/minute/meter) }\end{array}$} \\
\cline { 2 - 3 } & O.K & Not O.K \\
\hline$<5$ & $<25(0,02)$ & $>50(0,03)$ \\
\hline $5-10$ & $<50(0,03)$ & $>100(0,07)$ \\
\hline
\end{tabular}




\begin{tabular}{|c|c|c|}
\hline \multirow[t]{2}{*}{ Dam height (m) } & \multicolumn{2}{|c|}{$\begin{array}{l}\text { Seepage : Litres/day/meter } \\
\text { (Litres/minute/meter) }\end{array}$} \\
\hline & O.K & Not O.K \\
\hline $10-20$ & $<100(0.07)$ & $>200(0.14)$ \\
\hline $20-40$ & $<200(0.14)$ & $>400(0.28)$ \\
\hline $40>$ & $<400(0.28)$ & $>800(0.56)$ \\
\hline
\end{tabular}

Sumber: $\quad$ Quies 2002 dalam Look 2007

Selain itu, analisis terhadap rembesan yang melewati tubuh bendungan juga dapat diketahui dari index rembesannya (QI). Jika QI $<1$, maka rembesan yang terjadi pada tubuh bendungan masih normal dan tidak menimbulkan kebocoran dan ketidakstabilan pada tubuh bendungan (Novak, 2008). Persamaan indeks debit rembesan ditunjukkan pada Persamaan (3).

$$
Q I=\frac{q}{1000 . A \cdot i \cdot k}
$$

dimana :

QI : Seepage index (index debit rembesan)

$q \quad$ : Debit rembesan melalui tubuh bendungan per satuan lebar $(\mathrm{lt} / \mathrm{s} / \mathrm{m})$

$A \quad$ : Luasan elemen $\left(\mathrm{m}^{2}\right)$

$k \quad$ : Koefisien permeabilitas maksimum pada inti bendungan $(\mathrm{m} / \mathrm{s})$

$i \quad$ : Gradien hidraulik rata-rata yang melewati inti Bendungan.

Gradien hidrolik didasarkan pada konsep dari Teori Bernoulli, bahwa pada suatu jarak $\Delta \mathrm{L}$ nilai gradien hidrolik adalah konstan pada tiap kedalaman dan besarnya sama dengan kemiringan muka air tanah (Tanchev, 2014). Pehitungan gradien hidrolik berdasarkan konsep Teori Bernoulli dapat dilihat pada Persamaan (4).

$$
i=\frac{h}{\Delta l}
$$

di mana :

i : Gradien hidrolik

$\Delta l \quad$ : Panjang aliran yang mengalami kehilangan tinggi tekan (m)

$h \quad$ : Kehilangan energi (head loss) antara titik $\mathrm{A}$ dan $\mathrm{B}(\mathrm{m})=h_{A}-h_{B}$

\section{HASIL DAN PEMBAHASAN}

\section{Data Teknis Bendungan Kedung Ombo}

Bendungan Kedung Ombo terdiri atas bangunan utama berupa tubuh bendungan urukan serta beberapa bangunan pelengkap seperti bangunan pelimpah, bangunan pengambilan, terowongan pengelak serta instrumen pemantau keamanan bendungan. Bendungan utama adalah bendungan urukan tanah dan batu dengan inti (core) tegak. Lereng hulu dari inti tersebut dilindungi dengan filter transisi dan zona timbunan batu dengan perlindungan rip-rap. Lereng hilir dari inti juga dilengkapi dengan filter halus kemudian filter transisi dan timbunan random.

Ringkasan mengenai data teknis Bendungan Kedung Ombo adalah sebagai berikut (Laporan Rencana Tindak Darurat Bendungan Kedung Ombo (2017) dan Kedung Ombo Dam Project Construction Supervision, Report on Geology and Materials (1989) dapat dilihat pada Gambar 2.

$$
\begin{array}{ll}
\text { Tinggi Bendungan } & : 61 \mathrm{~m} \\
\text { Panjang Puncak Bendungan } & : 1.600 \mathrm{~m} \\
\text { Elevasi Puncak Bendungan } & :+96 \mathrm{~m} \\
\text { Elevasi Mukai Air Banjir Maks. } & :+95 \mathrm{~m} \\
\text { Elevasi Muka Air Normal Maks. } & :+90 \mathrm{~m} \\
\text { Elevasi Mukai Air Normal Min. } & :+65 \mathrm{~m} \\
\text { Volume Tampungan Total } & : 723 \times 10^{6} \mathrm{~m}^{3} \\
\text { Luas Daerah Genangan Waduk } & : 46,0 \mathrm{~km}^{2} \\
\text { Debit Inflow Tahunan Rata-Rata } & : 25,0 \mathrm{~m}^{3} / \mathrm{dt} \\
\text { Koefisien Permeabilitas Inti } & : 0,003 \times 10^{-8}- \\
& 0,14 \times 10^{-8} \mathrm{~m} / \mathrm{s}
\end{array}
$$

\section{Analisis Rembesan Instrumen -Notch}

Secara umum jumlah seepage observation ( $V$ Notch) di Bendungan Kedung Ombo masih memadai untuk mengetahui jumlah rembesan yang ada. Menurut desain, sebesar $90 \%$ rembesan di Bendungan Kedung Ombo dilewatkan melalui W2 (Lihat Gambar 3). Analisis terhadap data pengamatan rembesan di Bendungan Kedung Ombo dilakukan dengan membandingkan debit rembesan yang terjadi di Bendungan Kedung Ombo dengan elevasi muka air waduk dan curah hujan. Debit Rembesan yang dibandingkan merupakan jumlah debit rembesan yang terukur di W2, W3 dan W4. Hasil pencatatan terhadap debit rembesan yang terjadi dari tahun 2008 hingga tahun 2020 disajikan dalam Gambar 4. 
Dalam analisis rembesan ini, data bacaan debit rembesan yang digunakan adalah data bacaan harian di mana tidak terjadi hujan dan tidak dipengaruhi oleh musim hujan, sehingga dapat diketahui rembesan murni tanpa dipengaruhi oleh air hujan. Hal ini dilakukan dengan cara menyeleksi data bacaan saat tidak terjadi hujan dan menggunakan data pada musim kemarau tanpa hujan, hasil bacaan debit V-Notch dapat dipakai untuk analisis lebih lanjut. Data yang digunakan untuk analisis rembesan adalah bacaan debit VNotch dan elevasi muka air waduk yang memiliki korelasi antara keduanya (asumsi diambil tidak ada bagian yang bocor atau adanya clogging pada filter dan tidak ditemukan bocoran pada tubuh bendungan dan hasil pembacaan piezometer menunjukkan kondisi garis freatik tidak memotong lereng hilir bendungan) di mana semakin tinggi elevasi muka air waduk maka semakin besar debit rembesan dan demikian pula sebaliknya.

Berdasarkan hasil seleksi data diperoleh data yang dapat digunakan untuk analisis debit rembesan. Kemudian terhadap data tersebut dilakukan analisis regresi untuk mendapatkan persamaan regresi yang menggambarkan hubungan antara elevasi muka air waduk dan debit rembesan yang terjadi pada tubuh Bendungan Kedung Ombo. Hasil analisis regresi tersebut dapat dilihat pada Gambar 5.

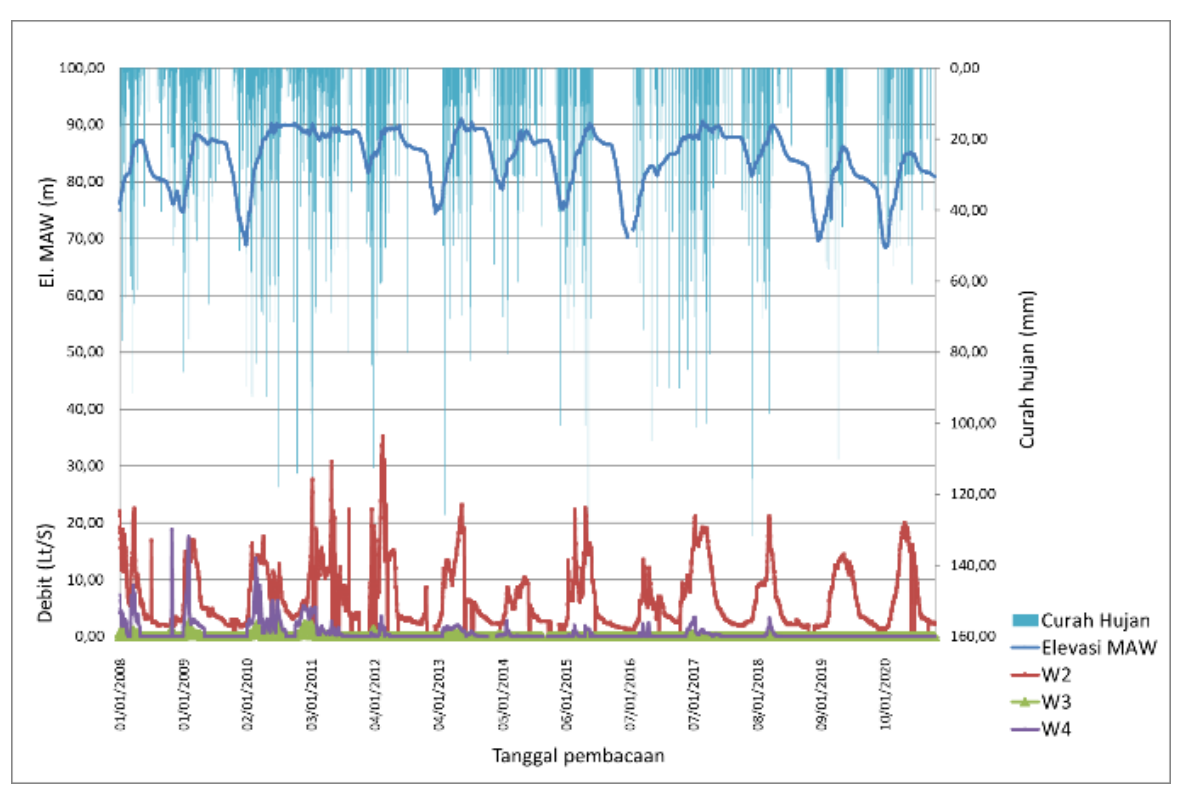

Gambar 4 Hasil Pencatatan V-Notch tahun 2008-2020, Curah Hujan dan Muka Air Waduk

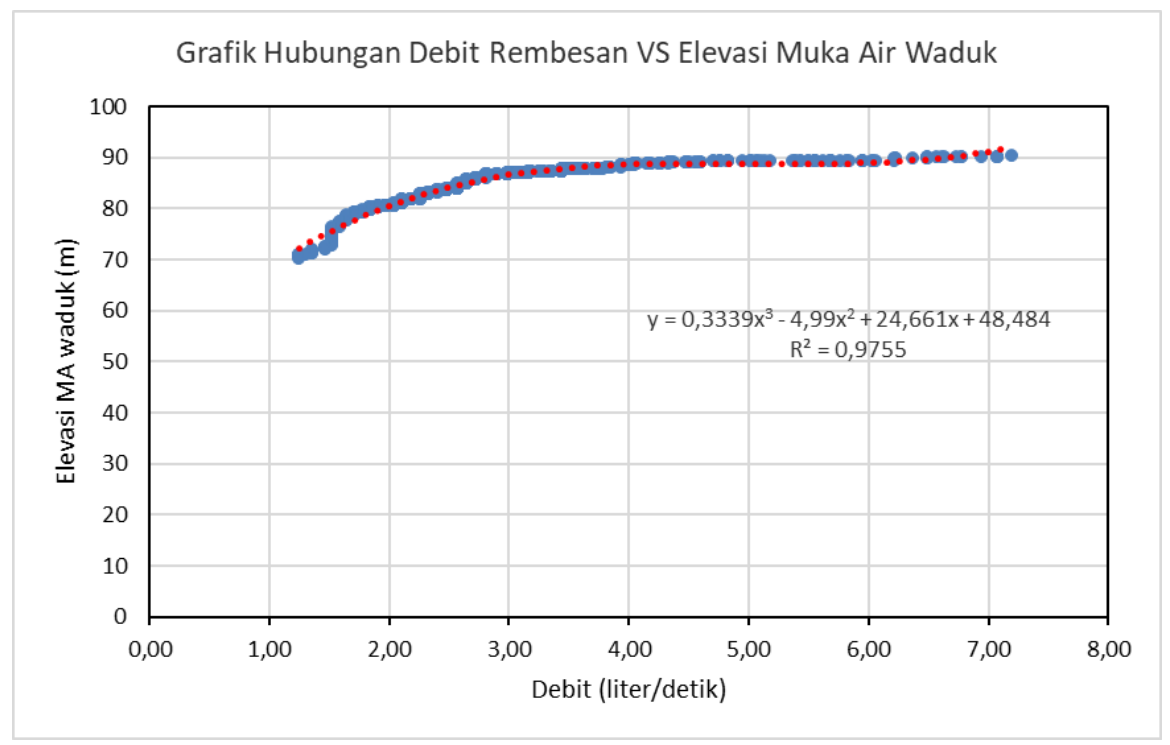

Gambar 5 Hubungan Debit Rembesan vs Elevasi Muka Air Waduk 
Berdasarkan hasil analisis regresi polinomial orde 3 diperoleh hubungan antara debit rembesan dan elevasi muka air waduk dengan persamaan $\mathrm{y}=$ $0,3339 x^{3}-4,99 x^{2}+24,661 x+48,484$ dengan koefisien regresi (R) sebesar 0,9877. Nilai koefisien korelasi yang diperoleh sangat tinggi bahkan hampir mendekati satu. Persamaan tersebut digunakan untuk analisis debit rembesan pada muka air normal maksimum dan banjir, yaitu pada elevasi +90 m, +91 m, +92 m, +93 m, +94 m, dan +95 $m$. Hasil analisis rembesan dan kriteria rembesan dapat dilihat pada Tabel 3.

Tabel 3 Debit dan Kriteria Rembesan

\begin{tabular}{|c|c|c|c|c|c|}
\hline \multirow{3}{*}{$\begin{array}{c}\text { El. MA } \\
\text { Waduk } \\
\text { m }\end{array}$} & \multirow{2}{*}{\multicolumn{2}{|c|}{ Rembesan }} & \multicolumn{2}{|c|}{$\begin{array}{c}\text { Kriteria Rembesan } \\
\text { (Queis, } 2002 \text { dalam } \\
\text { Look, 2007) }\end{array}$} & \multirow{3}{*}{ Ket. } \\
\hline & & & OK & not OK & \\
\hline & It/s & $\mathrm{It} / \mathrm{min} / \mathrm{m}$ & \multicolumn{2}{|c|}{$\mathrm{It} / \mathrm{min} / \mathrm{m}$} & \\
\hline 95 & 7,707 & 0,289 & $<0,28$ & $>0,56$ & ANTARA \\
\hline 94 & 7,561 & 0,284 & $<0,28$ & $>0,56$ & ANTARA \\
\hline 93 & 7,395 & 0,277 & $<0,28$ & $>0,56$ & OK \\
\hline 92 & 7,202 & 0,270 & $<0,28$ & $>0,56$ & OK \\
\hline 91 & 6,966 & 0,261 & $<0,28$ & $>0,56$ & OK \\
\hline 90 & 6,649 & 0,249 & $<0,28$ & $>0,56$ & OK \\
\hline
\end{tabular}

Berdasarkan hasil analisis rembesan di atas, debit rembesan yang terjadi pada tubuh bendungan pada elevasi muka air +93 m masih di bawah ambang batas aman, sehingga rembesan masih diizinkan. Namun pada muka air banjir maksimum elevasi +94 m dan +95 m, rembesan yang terjadi berada di antara ambang batas aman dan tidak aman. Dengan demikian perlu dilakukan analisis rembesan lebih lanjut berdasarkan Seepage Index untuk elevasi muka waduk +94 m dan +95 m untuk mengetahui keamanan rembesan pada tubuh bendungan.

\section{Analisis Tekanan Air Pori Piezometer}

Pengamatan tekanan air pori melalui piezometer pada tubuh bendungan dilakukan dengan cara mengeplotkan hasil pembacaan pada potongan tubuh bendungan. Dengan cara tersebut akan diketahui posisi tekanan air pori pada tubuh bendungan sehingga akan dapat diketahui apakah tekanan muka air pori masih dalam kondisi yang normal atau tidak. Analisis terhadap data series pembacaan instrumentasi pemantau tekanan pori dapat digambarkan dalam gambar dan grafik. Masing-masing grafik selalu dihubungkan dengan elevasi muka air waduk pada saat pengamatan.
Data yang digunakan adalah data series pengamatan piezometer hidraulik dari tahun 2003 hingga tahun 2020. Hasil pembacaan piezometer hidraulik (HP11, HP12, HP13, HP15, HP18, HP19, HP20, HP21, HP22, HP23, HP24, HP25, HP26, HP27, HP28, HP29, HP30, HP31, HP32 dan HP33) dan piezometer elektrik (EP1, EP2, EP3, EP5, EP6, EP8, EP9, EP10, EP12, EP13, EP14, EP15, dan EP16) ditampilkan dalam Gambar 6.

Sama seperti V-Notch sebelumnya, data bacaan tekanan air pori yang digunakan adalah data bacaan harian dimana tidak terjadi hujan dan tidak dipengaruhi oleh musim hujan sehingga dapat diketahui tekanan air pori murni tanpa dipengaruhi oleh air hujan. Berdasarkan hasil seleksi data didapatkan data yang dapat digunakan untuk analisis tekanan air pori. Kemudian data tersebut dilakukan analisis regresi untuk mendapatkan persamaan regresi yang menggambarkan hubungan antara elevasi muka air waduk dan tekanan air pori yang terjadi pada tubuh Bendungan Kedung Ombo. Sebagai satu contoh, hasil analisis regresi data pembacaan piezometer HP11 dapat dilihat pada Gambar 7.

Berdasarkan hasil analisis regresi linier untuk masing-masing instrumen piezometer diperoleh hubungan antara tekanan air pori dan elevasi muka air waduk dimana koefisien regresi (R) berkisar antara 0,81-0,97. Nilai koefisien korelasi yang diperoleh sangat tinggi. Dengan demikian persamaan tersebut dapat digunakan untuk analisis tekanan air pori pada muka air normal maksimum dan banjir yaitu pada elevasi $+90 \mathrm{~m},+91 \mathrm{~m},+92 \mathrm{~m}$, +93 m, +94 m, dan +95 m. Hasil analisis tekanan air pori Bendungan Kedung Ombo dapat dilihat pada Gambar 8 sampai Gambar 13.

Berdasarkan hasil analisis tekanan air pori pada Gambar 8 s/d 13, dapat diketahui bahwa inti kedap air, filter dan drain bendungan bekerja sesuai dengan yang diharapkan dimana garis freatik tidak melalui lereng hilir tubuh bendungan. Dengan demikian, Bendungan secara penggambaran flownet masih aman terhadap rembesan, baik dalam kondisi muka air normal maksimum (+90 m) maupun muka air banjir maksimum (+95 m).

Berdasarkan data tekanan air pori pada inti bendungan, selanjutnya dilakukan perhitungan gradien hidraulik untuk analisis indeks rembesan (seepage index). Hasil perhitungan gradien hidraulik dan seepage index ditampilkan pada Tabel 4 dan Tabel 5. 


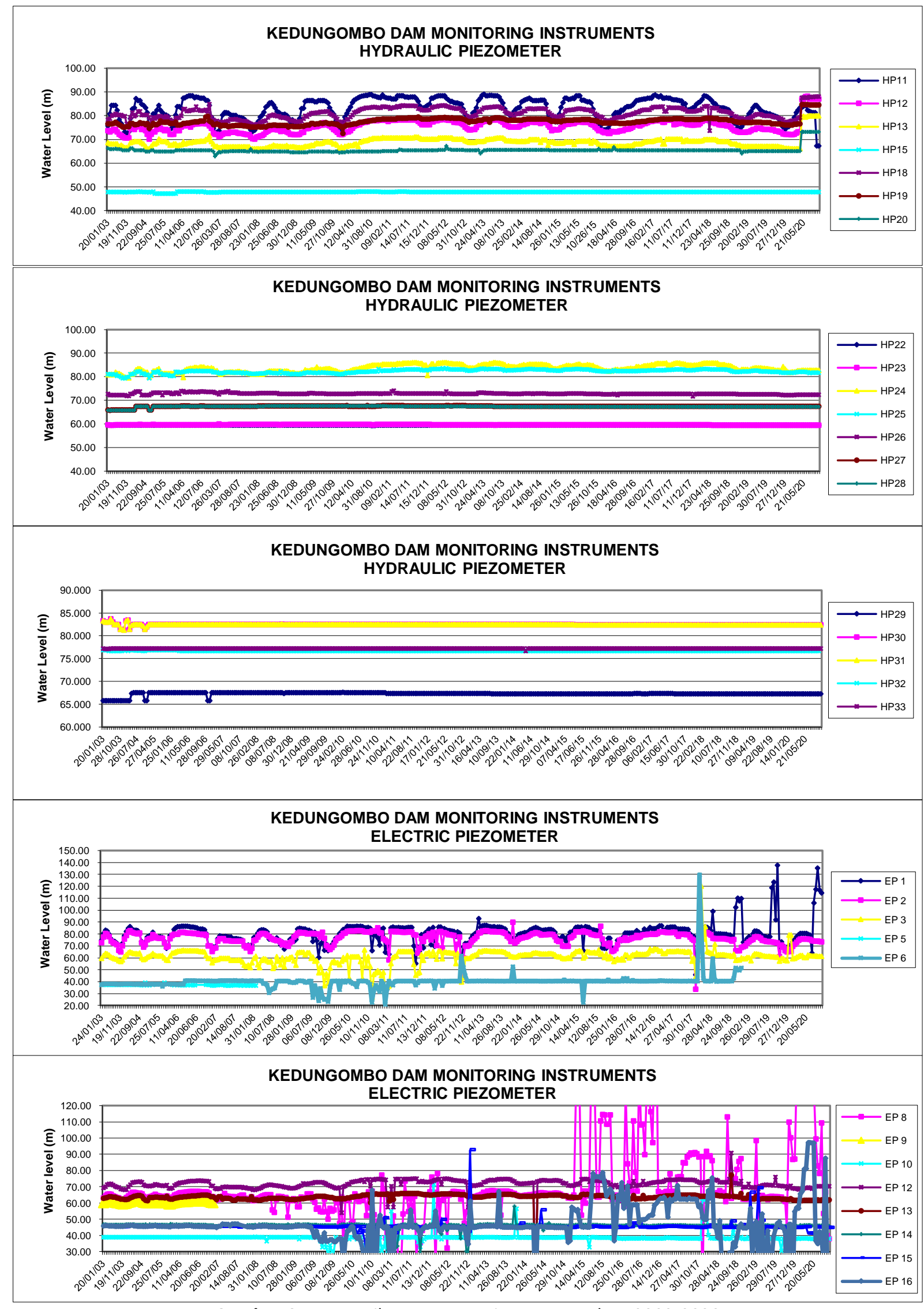

Gambar 6 Data Hasil Pencatatan Piezometer tahun 2003-2020 


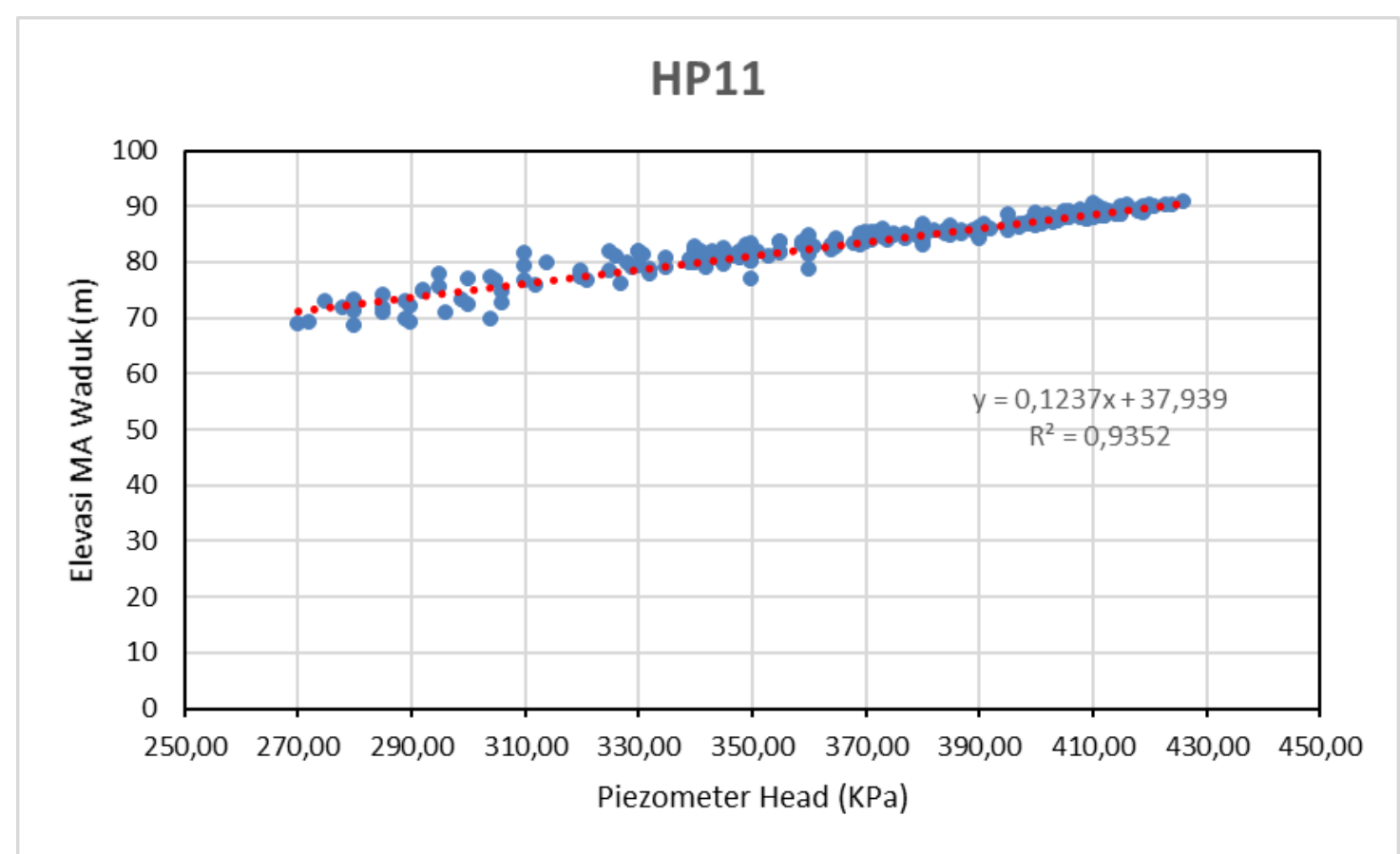

Gambar 7 Hubungan pembacaan piezometer vs Elevasi Muka Air Waduk

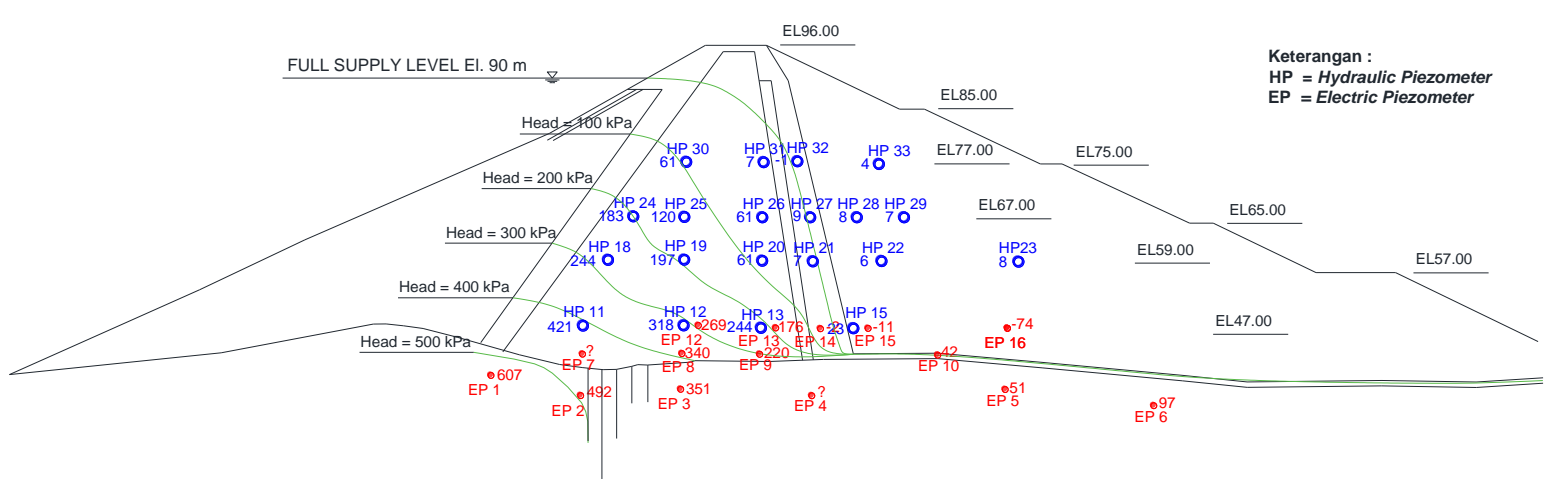

Gambar 8 Kontur Tekanan Air Pori di Tubuh Bendungan pada Elevasi Muka Air Normal Maksimum +90 m

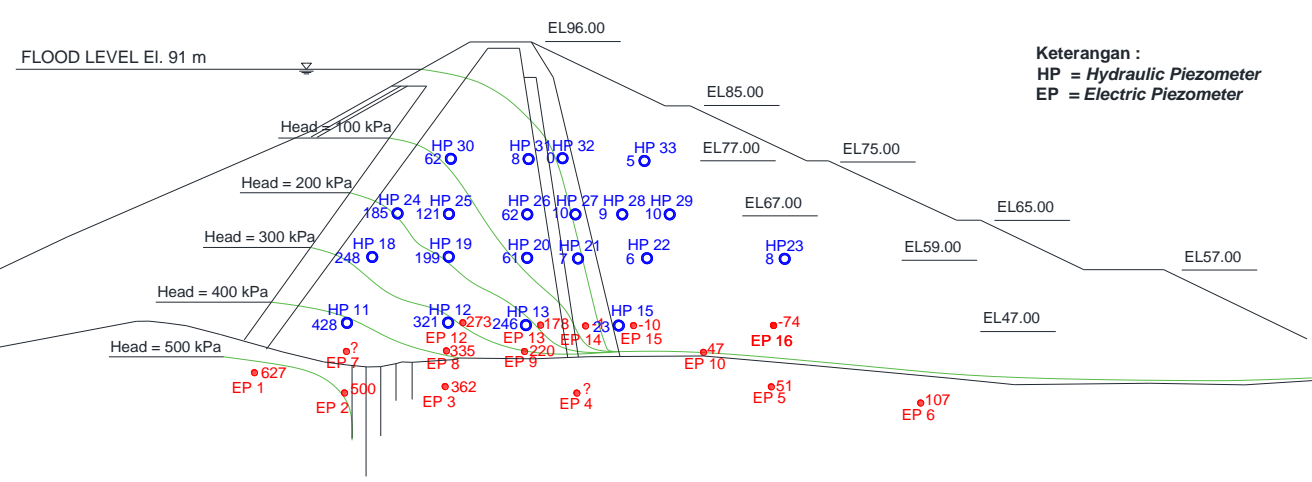

Gambar 9 Kontur Tekanan Air Pori di Tubuh Bendungan pada Elevasi Muka Air Banjir +91 m 


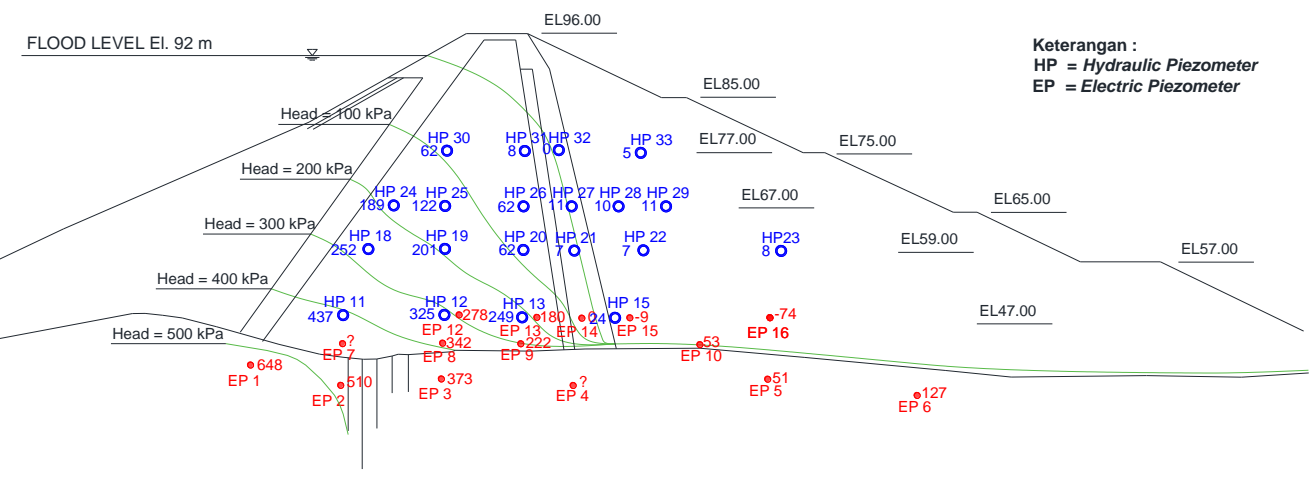

Gambar 10 Kontur Tekanan Air Pori di Tubuh Bendungan pada Elevasi Muka Air Banjir +92 m

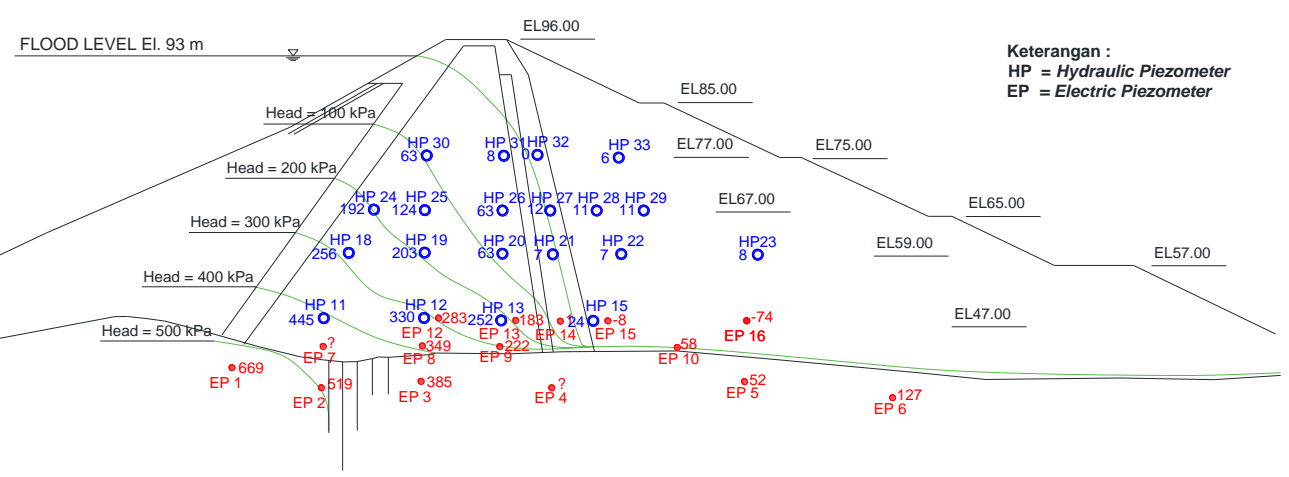

Gambar 11 Kontur Tekanan Air Pori di Tubuh Bendungan pada Elevasi Muka Air Banjir +93 m

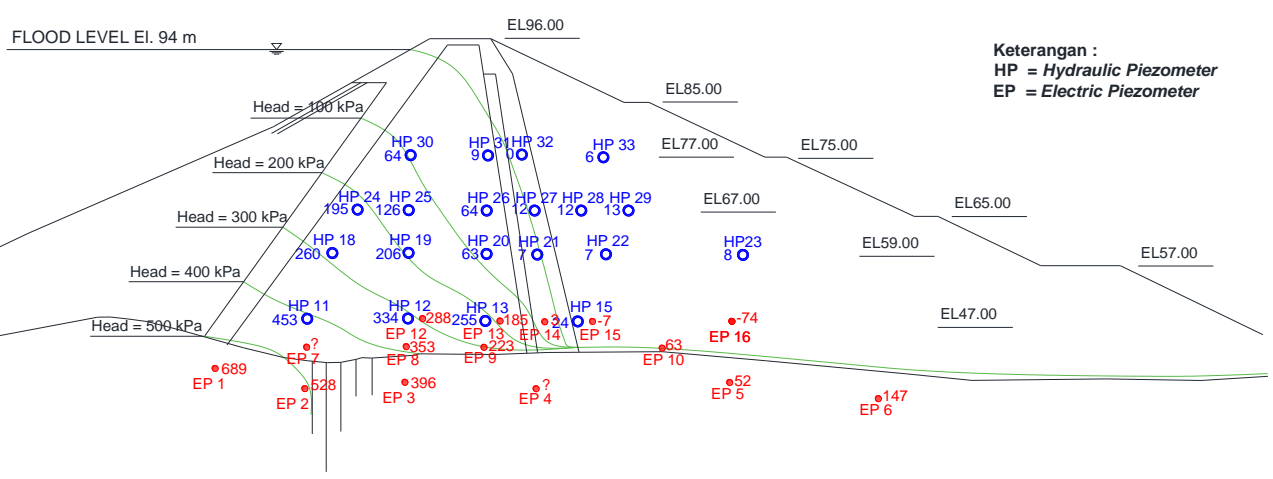

Gambar 12 Kontur Tekanan Air Pori di Tubuh Bendungan pada Elevasi Muka Air Banjir +94 m

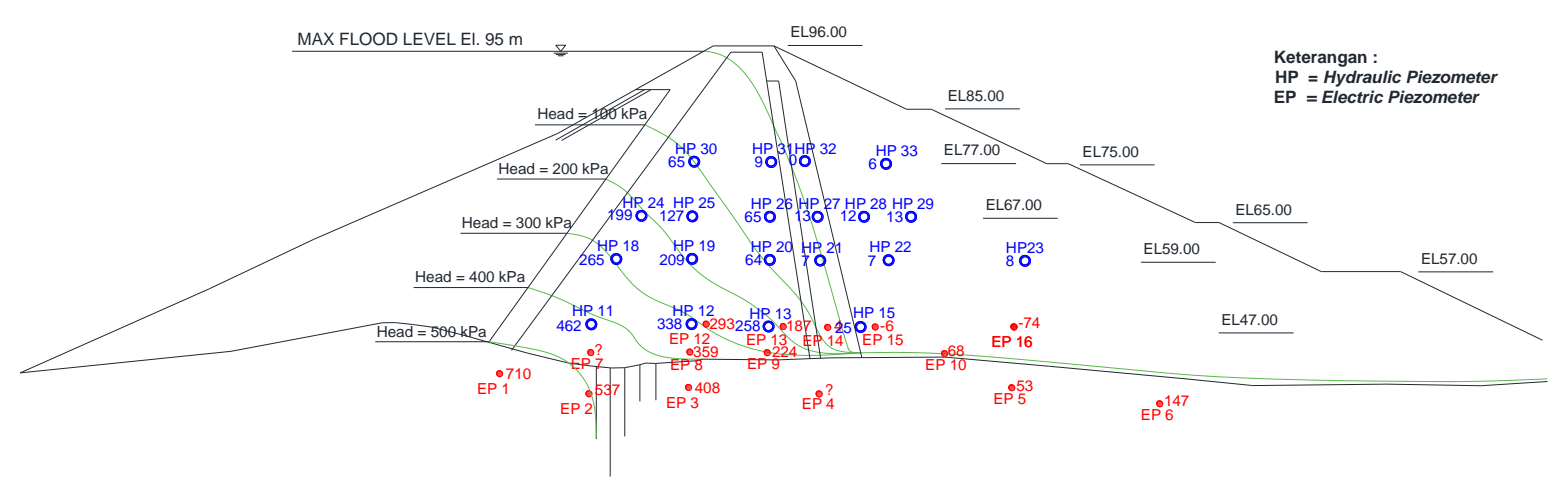

Gambar 13 Kontur Tekanan Air Pori di Tubuh Bendungan pada Elevasi Muka Air Banjir Maksimum +95 m 
Jurnal Teknik Hidraulik, Vol. 12 No. 2, Desember 2021. Hal : 79-92

Tabel 4 Perhitungan Gradien Hidraulik (i)

\begin{tabular}{|c|c|c|c|c|c|c|c|c|c|}
\hline $\begin{array}{l}\text { El. MA } \\
\text { Waduk }\end{array}$ & $\begin{array}{l}\text { Rembesan } \\
\text { V-Notch }\end{array}$ & $\mathrm{HP} \mathrm{U} / \mathrm{S}$ & $\begin{array}{c}\mathrm{HP} \text { U/S } \\
\text { Head }\end{array}$ & $\mathrm{HP} D / \mathrm{S}$ & $\begin{array}{c}\mathrm{HP} D / \mathrm{S} \\
\text { Head }\end{array}$ & $\Delta \mathrm{H}$ & L & $\mathrm{i}=\Delta \mathrm{H} / \mathrm{L}$ & Gradien Hidraulik (i) \\
\hline $\mathrm{m}$ & $\mathrm{It} / \mathrm{s} / \mathrm{m}$ & No. & $\mathrm{m}$ & No. & $\mathrm{m}$ & $\mathrm{m}$ & $\mathrm{m}$ & & Maks. \\
\hline \multirow{4}{*}{95,00} & \multirow{4}{*}{0,0048} & 30 & 83,44 & 31 & 77,76 & 5,68 & 14,22 & 0,40 & \multirow{4}{*}{0,72} \\
\hline & & 24 & 87,25 & 26 & 73,59 & 13,66 & 23,73 & 0,58 & \\
\hline & & 18 & 85,93 & 20 & 65,40 & 20,53 & 28,34 & 0,72 & \\
\hline & & 11 & 92,70 & 13 & 72,00 & 20,70 & 32,74 & 0,63 & \\
\hline \multirow{4}{*}{94,00} & \multirow{4}{*}{0,0047} & 30 & 83,36 & 31 & 77,72 & 5,64 & 14,22 & 0,40 & \multirow{4}{*}{0,71} \\
\hline & & 24 & 86,94 & 26 & 73,51 & 13,43 & 23,73 & 0,57 & \\
\hline & & 18 & 85,50 & 20 & 65,33 & 20,18 & 28,34 & 0,71 & \\
\hline & & 11 & 91,87 & 13 & 71,70 & 20,17 & 32,74 & 0,62 & \\
\hline \multirow{4}{*}{93,00} & \multirow{4}{*}{0,0046} & 30 & 83,29 & 31 & 77,68 & 5,61 & 14,22 & 0,39 & \multirow{4}{*}{0,70} \\
\hline & & 24 & 86,63 & 26 & 73,44 & 13,19 & 23,73 & 0,56 & \\
\hline & & 18 & 85,07 & 20 & 65,26 & 19,82 & 28,34 & 0,70 & \\
\hline & & 11 & 91,05 & 13 & 71,40 & 19,65 & 32,74 & 0,60 & \\
\hline \multirow{4}{*}{92,00} & \multirow{4}{*}{0,0045} & 30 & 83,21 & 31 & 77,63 & 5,58 & 14,22 & 0,39 & \multirow{4}{*}{0,69} \\
\hline & & 24 & 86,32 & 26 & 73,36 & 12,95 & 23,73 & 0,55 & \\
\hline & & 18 & 84,64 & 20 & 65,18 & 19,46 & 28,34 & 0,69 & \\
\hline & & 11 & 90,22 & 13 & 71,10 & 19,12 & 32,74 & 0,58 & \\
\hline \multirow{4}{*}{91,00} & \multirow{4}{*}{0,0044} & 30 & 83,13 & 31 & 77,59 & 5,54 & 14,22 & 0,39 & \multirow{4}{*}{0,67} \\
\hline & & 24 & 86,00 & 26 & 73,29 & 12,72 & 23,73 & 0,54 & \\
\hline & & 18 & 84,21 & 20 & 65,11 & 19,10 & 28,34 & 0,67 & \\
\hline & & 11 & 89,40 & 13 & 70,80 & 18,60 & 32,74 & 0,57 & \\
\hline \multirow{4}{*}{90,00} & \multirow{4}{*}{0,0042} & 30 & 83,05 & 31 & 77,55 & 5,51 & 14,22 & 0,39 & \multirow{4}{*}{0,66} \\
\hline & & 24 & 85,69 & 26 & 73,21 & 12,48 & 23,73 & 0,53 & \\
\hline & & 18 & 83,78 & 20 & 65,04 & 18,75 & 28,34 & 0,66 & \\
\hline & & 11 & 88,58 & 13 & 70,50 & 18,08 & 32,74 & 0,55 & \\
\hline
\end{tabular}

Sumber: $\quad$ Hasil Analisis

Tabel 5 Perhitungan Seepage Index (QI)

\begin{tabular}{|c|c|c|c|c|c|c|}
\hline $\begin{array}{l}\text { El. MA } \\
\text { Waduk }\end{array}$ & $\begin{array}{c}\text { Rembesan V- } \\
\text { Notch } \\
\text { (q) }\end{array}$ & $\begin{array}{l}\text { Luas } \\
\text { Penampang } \\
\text { (A) }\end{array}$ & $\begin{array}{c}\text { Koefisien } \\
\text { Permebilitas } \\
\text { (k) }\end{array}$ & $\begin{array}{l}\text { Gradien } \\
\text { Hidraulik } \\
\text { (i) }\end{array}$ & $\begin{array}{l}\text { Seepage } \\
\text { Index } \\
\text { (QI) }\end{array}$ & Keterangan \\
\hline $\mathrm{m}$ & $\mathrm{It} / \mathrm{s} / \mathrm{m}$ & $\mathrm{m}^{2}$ & $\mathrm{~m} / \mathrm{s}$ & & $\mathrm{Q} \mid<1$ & \\
\hline 95,00 & 0,0048 & 54.233 & 0,0000000014 & 0,72 & 0,09 & OK \\
\hline 94,00 & 0,0047 & 52.642 & 0,0000000014 & 0,71 & 0,09 & OK \\
\hline 93,00 & 0,0046 & 51.056 & 0,0000000014 & 0,70 & 0,09 & OK \\
\hline 92,00 & 0,0045 & 49.475 & 0,0000000014 & 0,69 & 0,09 & OK \\
\hline 91,00 & 0,0044 & 47.900 & 0,0000000014 & 0,67 & 0,09 & OK \\
\hline 90,00 & 0,0042 & 46.196 & 0,0000000014 & 0,66 & 0,08 & OK \\
\hline
\end{tabular}

Sumber: $\quad$ Hasil Analisis 
Berdasarkan hasil analisis seepage index, nilai QI tertinggi sebesar 0,11 pada elevasi muka air +95 $\mathrm{m}$, dimana kriteria keamanan seepage index $\mathrm{QI}<1$. Hasil analisis menunjukkan bahwa rembesan masih dalam batas yang diizinkan. Berdasarkan seepage index kondisi rembesan pada Bendungan Kedung Ombo masih dalam kondisi aman.

Bendungan Kedung Ombo perlu dilakukan pemeliharaan dan pemantauan secara rutin agar tidak terjadi suatu hal yang menyebabkan rembesan menjadi tidak aman. Namun demikian, jika di masa depan rembesan pada Bendungan Kedung Ombo karena suatu hal yang menyebabkan rembesan menjadi tidak aman, agar segera dilakukan tindakan untuk mencegah terganggunya stabilitas bendungan.

Studi pada Bendungan Panohan, kondisi rembesan yang terjadi pada Bendungan Panohan tidak aman terhadap rembesan. Kebocoran rembesan yang terjadi perlu segera diatasi karena dapat mengganggu stabilitas bendungan (Huda et al., 2019).

Salah satu metode yang dapat dilakukan untuk mencegah rembesan berlebih yaitu menambahkan tanggul/berm pada lereng hilir seperti pada Bendungan Franklin County di Mississipi, Amerika (FEMA, 2015).

\section{KESIMPULAN}

Berdasarkan hasil analisis rembesan di atas, dapat diambil kesimpulan bahwa tekanan air pori dan debit rembesan yang terjadi pada tubuh Bendungan Kedung Ombo secara umum masih dalam batas yang diizinkan. Berdasarkan hasil analisis seepage index di atas, Nilai QI tertinggi sebesar 0,09 pada elevasi muka air +95 m, dimana kriteria keamanan seepage index $\mathrm{Q} \mathrm{I}<1$. Berdasarkan seepage index kondisi rembesan pada Bendungan Kedung Ombo masih dalam kondisi aman.

\section{UCAPAN TERIMA KASIH}

Penulis mengucapkan terima kasih kepada semua pihak yang terkait (BPSDM Kementerian PUPR, Magister Teknik Sipil Universitas Diponegoro, BBWS Pemali Juana, Karyasiswa Super Spesialis Program Magister Retrofitting dan Instrumentasi Keamanan Bendungan Angkatan 2020, dan lain-lain), dimana telah membantu dukungan data maupun diskusi dalam penyelesaian studi ini. Semoga studi ini bermanfaat bagi yang berkepentingan dalam pemantauan keamanan bendungan khususnya terhadap rembesan.

\section{DAFTAR PUSTAKA}

Azdan, M. D., \& Samekto, C. R. (2008). Kritisnya Kondisi Bendungan di Indonesia 1. Seminar Nasional Bendungan Besar.

Balai Keamanan Bendungan. (2000). Keamanan Bendungan dalam Rangka Public Safety Assurance. November 2000, 2 p.

CDSO. (2016). Guidelines for Instrumentation of Large Dams Guidelines for Instrumentation of Large Dams Central Water Commission Ministry of Water Resources, River Development \& Ganga Rejuvenation Government of India. Book, September 2016. https://www.damsafety.in/ecmincludes/PDFs/Guidelines_for_Preparing_O\& M_Manuals_for_Dams.pdf

El-Hazek, A. N., Abdel-Mageed, N. B., \& Hadid, M. H. (2020). Numerical and experimental modelling of slope stability and seepage water of earthfill dam. Journal of Water and Land Development. https://doi.org/10.24425/jwld.2019.127046

FEMA. (2015). Evaluation and Monitoring of Seepage and Internal Erosion, Interagency Committee on Dam Safety (ICODS). Federal Emergency Management Agency, May.

Foster, M., Fell, R., \& Spannagle, M. (2000). The statistics of embankment dam failures and accidents. Canadian Geotechnical Journal. https://doi.org/10.1139/t00-030

Huda, A. L., Wardani, S. P. R., \& Suharyanto, S. (2019). Evaluasi Tekanan Air Pori dan Rembesan Pada Bendungan Panohan. Reka Buana: Jurnal IImiah Teknik Sipil Dan Teknik Kimia. https://doi.org/10.33366/rekabuana.v4i2.137 2

Indonesia, (2010). Peraturan Pemerintah Republik Indonesia Nomor 37 Tahun 2010 Tentang Bendungan. Lembaran Negara Republik Indonesia Tahun 2010 Nomor 45. Jakarta.

Look, B. G. (2007). Handbook of Geotechnical Investigation and Design Tables. https://doi.org/10.1201/9780203946602

Novak, P. (2008). Hydraulic structures. In Journal of Hydraulic Research (Vol. 46, Issue 5). https://doi.org/10.1080/00221686.2008.9521 916

Nurnawaty, N., Suhardiman, S., \& Ihwan, I. (2018). ANALISIS REMBESAN PADA BENDUNGAN TIPE URUGAN (UJI SIMULASI LAB). TEKNIK HIDRO. https://doi.org/10.26618/th.v11i1.2436 
Sugiyono. (2016). Metode Penelitian Kuantitatif, Kualitatif, dan R\&D, Alfabeta, CV. Bandung (2016).

Sujono, J. (2012). Hydrological analysis of the Situ Gintung dam failure. Journal of Disaster Research.

https://doi.org/10.20965/jdr.2012.p0590

Tanchev, L. (2014). Dams and appurtenant hydraulic structures - General. In Dams and Appurtenant Hydraulic Structures, 2nd edition. https://doi.org/10.1201/b16672-2

Triatmodjo, B. (2016). Hidraulika I. Yogyakarta: Beta Offset

Wulandari, P. S., \& Tjandra, D. (2019). Analisis Pengaruh Fluktuasi Muka Air Waduk terhadap Stabilitas Lereng Waduk Dengan Menggunakan Program Plaxis 2D. MEDIA KOMUNIKASI TEKNIK SIPIL. https://doi.org/10.14710/mkts.v24i2.17780

Zhang, C., Chai, J., Cao, J., Xu, Z., Qin, Y., \& Lv, Z. (2020). Numerical simulation of seepage and stability of tailings dams: A case study in lixi, China. Water

(Switzerland). https://doi.org/10.3390/w12030742 